\title{
New Frontiers of Necrotizing Enterocolitis: From Pathophysiology to Treatment
}

\author{
Umut Zubarioglu, Sinan Uslu*, Ali Bulbul \\ Division of Neonatology, Department of Pediatrics, Sisli Hamidiye Etfal Educational and Research Hospital, Istanbul, Turkey \\ Email: uzubari@hotmail.com, ^sinanuslumd@hotmail.com,drbulbul@yahoo.com
}

How to cite this paper: Zubarioglu, U., Uslu, S. and Bulbul, A. (2017) New Frontiers of Necrotizing Enterocolitis: From Pathophysiology to Treatment. Health, 9, 106123.

http://dx.doi.org/10.4236/health.2017.91008

Received: November 29, 2016

Accepted: January 10, 2017

Published: January 13, 2017

Copyright $\odot 2017$ by authors and Scientific Research Publishing Inc. This work is licensed under the Creative Commons Attribution International License (CC BY 4.0).

http://creativecommons.org/licenses/by/4.0/

(c) (i) Open Access

\begin{abstract}
Necrotizing enterocolitis [NEC] is an inflammatory disease of intestine largely occuring in preterm infants with a wide range of damage from minimal injury limited to mucosa to extensive necrosis of bowel wall and perforation. Despite advancements in neonatal care, mortality remains high [30\% - 50\%] and controversy still persists with regards to the most appropriate management of neonates with necrotizing enterocolitis. The main factors thought to be involved in the pathogenesis of NEC are: relatively hyper-reactive state of premature intestine, enteral feeding and bacterial colonization. In this review, we discuss current knowledge about the epidemiology, pathophysiology, imaging, medical and surgical management of necrotizing enterocolitis and describe novel strategies for prevention and treatment.
\end{abstract}

\section{Keywords}

Preterm Infants, Necrosis, Necrotizing Enterocolitis

\section{Introduction}

Necrotizing enterocolitis [NEC] is an inflammatory disease of intestine largely occur in preterm infants with a wide range of damage from minimal injury limited to mucosa to extensive necrosis of bowel wall and perforation. Necrotizing enterocolitis is the most common reason of death originated from intestinal tract in preterm babies especially for very low birth weight [VLBW] infants [1]. Although early recognition and aggressive treatment of this disorder has improved clinical outcomes, NEC accounts for substantial long-term morbidity in survivors of neonatal intensive care, particularly in VLBW infants.

Here, we will discuss current knowledge about epidemiology, pathophysiology, management strategies and describe new strategies about prevention and treatment. 


\section{Epidemiology}

Worldwide, large multicentre studies coordinated by neonatal research networks have determined the incidence of NEC to be up to $13 \%$ among infants born $\leq 33$ weeks of gestation or whose birth weight is $\leq 2500 \mathrm{~g}$ [1]-[9]. Although the majority of cases of NEC occur among premature infants, a small subset of babies born at term or $\geq 35$ weeks of gestation develop NEC-like gastrointestinal signs and symptoms, frequently in association with other conditions such as congenital heart disease, perinatal asphyxia, polycythemia, sepsis, and respiratory disease [10].

\section{Pathogenesis}

The main factors thought to be involved in the pathogenesis of NEC are: relatively hyper-reactive state of premature intestine, enteral feeding and intestinal microflora.

\subsection{Hyper-Reactive State of Premature Intestine}

To understand the reasons for why preterm babies are at a particularly high risk of developing NEC compared with term babies, researches have focused on identifying the differences between the premature and the full-term intestinal tract. These studies have shown significant differences in bacterial colonization, microcirculatory perfusion and the maturity of the innate immune system of gut [11] [12]. These differences can provide and explain us the multi-factorial pathogenesis of NEC. Major difference found in studies was expression of Tolllike receptor 4 [TLR4] at higher levels in the premature than the full-term intestine in mice, humans and other species [13]. The elevated expression of TLR4 in the premature gut is reflective to function of TLR4 exhibits in the regulation of normal gut development [13]. In the premature birth situation, intestinal TLR4 levels remain elevated and activation of TLR4 on the lining of the premature intestine by the Gram negative bacteria that colonize the premature gut leads to a number of deleterious effects, including increased enterocyte apoptosis, impaired mucosal healing and enhanced proinflammatory cytokine release, which in aggregate lead to the development of NEC [14] [15]. Also, the translocation of Gram-negative bacteria through the gut mucosa leads to activation of TLR4 on the lining of the endothelium of the premature bowel mesentery, resulting in a reduction in blood flow and the development of intestinal ischaemia and necrosis [16]. This explanation for the pathogenesis of NEC termed as "the cross-switching hypothesis" partially explains the reasons for which the premature infant is at risk of NEC development and why the disease occurs upon bacterial colonization.

Also additional factors are known to differ between the premature and fullterm host that might contribute to this disease.

- high baseline level of cellular endoplasmic reticulum stress within the premature intestine which increases the likelihood of apoptosis in the epithelial lining [17]. 
- the decreased number of mucus-producing goblet cells in the premature intestine results in deficient mechanical protection [13] [18].

- the impaired clearance of luminal contents, owing to decreased motility [19] [20] [21] [22].

- decreased digestion and absorption as a result of enterocyte immaturity [23] [24].

- increased microvascular tone within the preterm intestinal mesentery [16] [25].

- presence of immature tight junctions [26] [27].

All of these factors can render the bowel at risk of proinflammatory signalling, bacterial translocation and NEC development [19] [25] [28]. Notably, some of these important factors are linked to TLR4 signalling. Furthermore, T lymphocytes have been shown to participate in the adaptation of the premature intestinal mucosa to bacterial colonization and contribute to NEC development [29] [30]. NEC is associated with lymphocyte imbalance within the intestinal mucosa, as TLR4 signalling in the intestinal epithelium leads to an upregulation of proinflammatory $\mathrm{T}$ helper 17 cells and a reduction in protective $\mathrm{T}$ regulatory cells [30]. Specifically, various investigators have identified roles for the increased expression and function of platelet-activating factor in the mucosal injury and barrier dysfunction associated with NEC [28] [31] [32]. Infants with NEC have high circulating levels of platelet-activating factor associated with the increased expression of this protein as well as with deficient activity of plateletactivating factor acetylhydrolase, the enzyme involved in its degradation [31] [33] [34]. Additionally, platelet-activating factor has been demonstrated to induce TLR4 expression and signalling [28] [35].

\subsection{Enteral Feeding}

There have been 2 conditions known about relationship between enteral feeding and NEC; which are predominance of enterally fed premature babies in NEC epidemiology and protective effects of human milk against NEC [36]. A wide range of protective ingredients present in breast milk has been appointed and some part of them have been found as promising agents in NEC prevention and treatment [37]. Recent researches suggested the epigenetic effects of diet type on intestinal genomic structure. Human milk and other enterally given products change gene expression especially with methylation [38]. In studies performed in preterm infants and pig models, it was shown that proinflamatory genes became upregulated by enteral feeding [39] [40]. Also important risk factors in NEC pathogenesis such as intestinal microflora and intestinal splanhenic perfusion has mutual interaction with enteral feeding type [41] [42].

\subsection{Intestinal Microflora}

How bacterial pathogens involve in NEC pathophysiology still unclear but studies showed that they got interaction with several ways [36]. The most important evidence about bacterial involvement is occurence of NEC as out- 
breaks occasionally with the grown of same organisms from babies' cultures and such clusters of cases got controlled with the start of infection control measures [43] [44]. However, differents centers reported separate microorganisms are grown in their outbreaks so someone can not claimed NEC development dedicated to a distinct bacterial agent. Also researchers found that endotoxinemia, blood culture growns by bacteria and 30\% hydrogen content of pneumatosis [an unique gas produced only by bacteria] in their studies which were demonstrate association of bacteria with NEC pathogenesis [45] [46] [47].

Earlier studies about NEC pathogenesis suggested the "dysbiosis" hypothesis [48]. Even so, recent studies claimed that bacterial diversity in microflora of gut disappeared just before beginning of NEC with following domination of pathogenic bacteria [49] [50].

\section{Diagnosis}

The cornerstone of effective NEC treatment relies on accurately diagnosing the disease, which can usually be established on the basis of readily available clinical, radiographic and laboratory data. The typical neonate with NEC is a premature infant who is thriving, yet suddenly presents with feeding intolerance, abdominal distension, bloody stools and signs of sepsis [11] [51]. For descriptive purposes and for disease stratification, the Bell scoring system has been widely utilized, which assesses the degree of NEC severity as mild [Bell stage I], moderate [Bell stage II] or severe [Bell stage III], as shown in Table 1.

\section{Biomarkers and Noninvasive Testing for the Diagnosis of NEC}

The relative nonspecificity of the readily available clinical and radiographic tests suggest the need for additional molecular markers to improve early diagnosis of NEC in premature infants. In this regard, the presence of several molecules that are detected in the blood have been assessed for their value in establishing the diagnosis of NEC and a number of them have shown considerable promise, including acute-phase reactants [such as C-reactive protein] and proinflammatory cytokines [for example, TNF $\alpha$, IL- 6 and IL-8] which were found as nonspecific [55] [56] [57].

In addition, organ-specific biomarkers, such as those that would indicate enterocyte injury or intestinal barrier impairment, include intestinal fatty acidbinding protein, liver fatty acid-binding protein, faecal calprotectin studied for early identicifation of NEC [58] [59]. Among these circulating molecules, one of the most promising might be intestinal fatty acid-binding protein, a cytoplasmic protein involved in enterocyte lipid metabolism that is released into circulation and secreted into the urine after enterocyte damage, which has been suggested to be useful in the prediction of NEC development and to correlate with the extent of intestinal necrosis [53] [60]. Neverthless, I-FABP has handicaps in detection of NEC in early stages. Plasma half life is short and normal values in healthy preterm babies are variable that limits the use of I-FABP [36]. Also some NEC cases with extensive necrosis with ongoing damage can come against us with low 
Table 1. Modified Bell staging criteria for necrotizing enterocolitis [52] [53] [54].

\begin{tabular}{|c|c|c|c|c|c|}
\hline Stage & 1 & $2 \mathrm{~A}$ & $2 B$ & $3 \mathrm{~A}$ & $3 B$ \\
\hline Description & Suspected & Mild & Moderate & Severe & Severe \\
\hline $\begin{array}{l}\text { Systemic } \\
\text { signs }\end{array}$ & $\begin{array}{c}\text { Temperature } \\
\text { instability, } \\
\text { apnea, } \\
\text { bradycardia }\end{array}$ & $\begin{array}{l}\text { Similar to } \\
\text { stage } 1\end{array}$ & $\begin{array}{l}\text { Mild acidosis, } \\
\text { trombocytopenia }\end{array}$ & $\begin{array}{l}\text { Respiratory } \\
\text { and } \\
\text { metabolic } \\
\text { acidosis, } \\
\text { need for } \\
\text { mechanical } \\
\text { ventilation, } \\
\text { hypotension, } \\
\text { oliguria, } \\
\text { disseminated } \\
\text { intravascular } \\
\text { coagulopathy }\end{array}$ & $\begin{array}{c}\text { Further } \\
\text { deterioration and } \\
\text { shock }\end{array}$ \\
\hline $\begin{array}{l}\text { Intestinal } \\
\text { signs }\end{array}$ & $\begin{array}{l}\text { Increased } \\
\text { gastric } \\
\text { residuals, } \\
\text { mild } \\
\text { abdominal } \\
\text { distention, } \\
\text { occult } \\
\text { blood in } \\
\text { the stool }\end{array}$ & $\begin{array}{c}\text { Marked } \\
\text { abdominal } \\
\text { distension } \pm \\
\text { tenderness, } \\
\text { absent bowel } \\
\text { sounds, } \\
\text { grossly } \\
\text { bloody stools }\end{array}$ & $\begin{array}{c}\text { Abdominal } \\
\text { wall edema } \\
\text { and } \\
\text { tenderness } \pm \\
\text { palpable mass }\end{array}$ & $\begin{array}{l}\text { Worsening } \\
\text { wall edema } \\
\text { with } \\
\text { erythema } \\
\text { and } \\
\text { induration }\end{array}$ & $\begin{array}{l}\text { Evidence of } \\
\text { perforation }\end{array}$ \\
\hline $\begin{array}{c}\text { Radiographic } \\
\text { signs }\end{array}$ & $\begin{array}{l}\text { Normal or } \\
\text { mild ileus }\end{array}$ & $\begin{array}{l}\text { Ileus, dilated } \\
\text { bowel loops, } \\
\text { focal } \\
\text { pneumatosis }\end{array}$ & $\begin{array}{c}\text { Extensive } \\
\text { pneumatosis, } \\
\text { early ascites } \pm \\
\text { portal } \\
\text { venous gas }\end{array}$ & $\begin{array}{l}\text { Prominent } \\
\text { ascites, } \\
\text { fixed bowel } \\
\text { loop, no } \\
\text { free air }\end{array}$ & pneumoperitoneum \\
\hline
\end{tabular}

I-FABP levels paradoxically because of this short half-life [53] [61]. In recent researches about biomarkers for NEC discovered novel urinary peptides and proteins which are linked to poor prognosis [62] [63].

Although plain radiology still accepted as the primary imaging procedure for diagnosis and staging the infants with NEC some new modalities especially ultrasound [US] has attracted research interest [64] [65]. Abdominal US can detect both pneumatosis intestinalis and portal venous gas [PVG] which is earlier than plain radiography especially for PVG [66]. Also US gives more details about perfusion and thickness of gut wall and motility from plain radiographs which may detect babies with more advanced disease and those who may benefit from surgery [67] [68].

Further information that can be obtained from ultrasound also includes the presence of free intraabdominal gas and the presence and nature of any free intraabdominal fluid that may be indicative of intestinal perforation [36].

Doppler ultrasonography can be used for evaluating coeliac trunk and superior mesenteric artery blood flow velocity, which can demonstrate cases at risk of necrotizing enterocolitis with poor perfusion, also for assessment of the intestinal wall viability in patients with NEC [54] [67] [68] [69] [70].

Near infra-red spectroscopy [NIRS] has got research interest recently which 
may be useful for risk prediction of NEC, separation of cases with NEC from those without and detection of advanced NEC [71] [72]. Important limitation for NIRS is placement of probes on the skin and tissue penetration has short depth. So, measures of NIRS may give only oxygenation of underlying intestine of probes rather than entire intestine. On the other hand, NIRS measures can be use to detect differences in splanchnic tissue oxygenation in preterm babies who subsequently developed NEC and those who did not [71] [72] [73].

\section{Prevention}

Given that NEC occurs in a well-defined population of patients who are premature, there might be benefit in identifying specific preventive strategies that, if administered successfully to the appropriate patients, could reduce the incidence of NEC. In this regard, there has been tremendous interest in developing specific nutritional and pharmacological strategies to reduce the incidence of NEC.

\subsection{The Use of Breast Milk}

Multiple randomized clinical trials have now validated the empirical observation that breast milk statistically significantly reduces the incidence of NEC [74] [75]. Human milk contains a variety of beneficial bioactive factors, among which several have been shown to reduce NEC incidence and progression [74] [76].

In Table 2, a list of human milk components which had protective effects against NEC presented.

Considerable research efforts have been deployed to identify these critical factors in the hope that new preventive strategies can be developed [75]. Although the precise mechanisms by which breast milk protects against NEC are not yet fully understood, emerging experimental evidence suggests that breast milk inhibits TLR4 signalling by preventing glycogen synthase kinase $3 \beta$ activity [77]. Consequently, breast milk-mediated downregulation of TLR4 signalling can reverse the inhibition of intestinal stem cell proliferation and mucosal healing, which are themselves inhibited by TLR4 [77] [78]. Moreover, these effects were shown to be partially dependent upon activation of epidermal growth factor

Table 2. Protective factors of human milk against NEC.

Laktoferrin
Oligosaccarides and prebiotics
Secretory IgA
L-arginine
Nitrate/Nitrite
Platelet-activating factor acetylhydrolase
Antioxidant factors
Growth factors [Epidermal GF, Heparin-binding EGF-like GF, Transforming GF $\left.\mathrm{B}_{2}\right]$
Erytropoietin


receptor signalling [77].

\subsection{Donor Milk}

The lack of availability of human breast milk [which can arise for a number of reasons, such as insufficient production by the mother of an infant remains a major challenge in neonatal care and has led to the use of donor breast milk as a potential substitute or supplement to formula-feeding [74] [79]. Multiple reports support the use of donor human milk as a potentially effective strategy for reducing the incidence of NEC [80] [81].

\subsection{Probiotics in the Prevention of NEC}

Probiotics are defined as live microorganisms that provide a health benefit to the host. These agents have been shown to protect against NEC and reduce disease severity and overall mortality in premature infants [82] [83]. The finding that a degree of perturbation in the normal gut microbial flora exists in patients with NEC supports a rationale of using probiotics to treat and prevent this disease [84] [85] [86]. Considering the vulnerability of premature infants, routine administration of probiotic agents has elicited substantial controversy regarding the type of agent to be used, dosing and timing [83] [87]. A systematic review evaluated the efficacy and safety of probiotics for preventing NEC and suggested that oral administration of probiotics decreases all-cause mortality and incidence of severe NEC in preterm infants; however, the precise probiotic agent, timing and length of therapy still remains to be established [83] [88]. Emerging consensus is that the use of probiotics in NEC could be effective in reducing the incidence of the disease without increasing rates of sepsis or other adverse events [88] [89] [90] [91].

Administration of the probiotic bacteria Lactobacillus rhamnosus was shown to increase enterocyte proliferation and differentiation of Paneth cells in enteroids grown in a 3D bioscaffold [92]. Furthermore, treatment with CpG-containing bacterial DNA, which bypasses the potential adverse effects of live bacteria, is effective against experimental NEC in mice and piglets, and acts by activating Toll-like receptor 9 and inhibiting TLR4, providing a potential alternative to the use of live probiotics [93].

\section{Treatment}

\subsection{Medical Supportive Management}

Most infants with Bell's stage I or stage II NEC are managed with appropriate supportive therapies which includes cessation of enteral nutrition, support of ventilation, stabilization of fluid-electrolyte and acid-base balances, correction of ongoing coagulopathy and/or thrombocytopenia, bowel rest, and antibiotics [54]. About which antibiotics should be used for NEC, there is still no sufficient evidence and concencus in literature and this confusion was demonstrated by both an international survey and a Cochrane review [94] [95]. So, antibiotics may be ordered according to protocol of center and regulated according to 
growns in cultures and sensitivity results of the case. Similarly, the optimal duration time for withholding enteral feds and bowel rest is not on evidencebased treatment and based on institutional approach [94].

\subsection{Surgical Management}

Surgical intervention is required in up to $50 \%$ of the NEC cases in large, population-based and hospital-based multicentre studies coordinated by neonatal research networks and typically includes the removal of necrotic intestine [5] [8] [9] [96] [97]. In rare cases, the placement of a peritoneal drain and abdominal irrigation might be sufficient. Although several studies have reported that patients undergoing peritoneal drainage and laparotomy could have similar outcomes [87] [94] [95]. Several surgical guidelines have been published [89] [98] [99] [100]. Given that up to $74 \%$ of infants initially managed with peritoneal drainage will require a subsequent laparotomy [96] [99] a commonly accepted approach has been to reserve primary peritoneal drainage for those patients with substantially elevated intra-abdominal pressure that impairs ventilation, or for extremely small infants under $750 \mathrm{~g}$.

\subsection{New Medical Treatments in Research}

In consequence of the role of hyper-reactive and immature immune system in NEC etiopathogenesis; research studies focused on new treatment agents that regulate the immune response. Pentoxifylline is one of these agents studied but a very weak evidence found for usage as combination therapy to antbiotics in neonatal sepsis in a Cochrane review with a relative risk of NEC of 0.62 [101] [102]. In another study which intra-peritoneal pentoxifylline used in neonatal rat model, it was found that NEC incidence and severity reduced [103].

\subsection{Promising New Agents}

- Stem cells; Recent evidences came from research groups suggested that amniotic fluid stem cells [AFS], mesenchymal stem cells and enteric neural stem system cells have potential to change the trend of the NEC in experimental models [104] [105] [106] [107] [108].

- Amniotic fluid; In experimental animal models, in vitro proliferation and migration of gut epithelial cells was provided by both porcine and human amniotic fluid [109]. In another study which amniotic fluid used in postnatal minimal enteral feeding of preterm piglets; NEC incidence, severity and inflammation decreased [110]. In a mouse model, it was shown that NEC severity also decreased with amniotic fluid given enterally which contains epidermal growth factor [EGF] and its receptor as major factor in this effect [111].

- Growth Factors; Heparin-binding EGF-like growth factor has been identified as a biologic agent capable of preventing NEC in various animal models, and of reversing the effects of established NEC, via positive effects on mucosal healing, intestinal stem cell function and vascular perfusion [112] 
[113] [114].

- TLR4 inhibitor; nontoxic oligosaccharide that inhibits TLR4 was shown to prevent NEC in mice and piglets and to reduce intestinal inflammation in ex vivo human intestine obtained during the treatment of NEC [32].

- Human milk oligosaccharides; established an important role for in NEC prevention and treatment [115] [116].

- Lactoferrin; Emerging evidence also suggests a prophylactic benefit against the development of NEC by oral administration of lactoferrin with or without probiotics to preterm infants at risk of NEC [gestational age $<32$ weeks or birth weight $<1500 \mathrm{~g}]$ [75].

\section{Outcome}

Despite advancement in medical and surgical treatment over the last decades, the average mortality from NEC is $20 \%-30 \%$, with mortality as high as $50 \%$ in those infants requiring surgical management [117]. Necrotizing enterocolitis has also severe morbidities affects survived infants which are originated from intestinal or systemic insults [54]. These complications include;

- Relapsing of NEC; About 10\% of babies who had undergone surgery for NEC develop a relapsing episode and this causes long-term parenteral nutrition dependency [54].

- Intestinal strictures; About $25 \%$ of patients who had NEC and especially treated surgically, can develop one or more intestinal strictures [54].

- Gut failure; İnfants who had undergone surgery for NEC will develop intestinal failure with high proportion and it depends on many factors (such as low birth weight, antibiotic use, ventilator use, and greater extent of bowel resection) also associated with NEC development [54].

- Parenteral nutrition associated complications

- Neurodevelopmental disturbances; seen in the nearly half of neonates, but by which mechanisms this develops is stil not identified clearly [118] [119]. It is found that infants with NEC had white matter anomalies on magnetic resonance imaging at term which increases the risk for motor impairment [120].

\section{Conclusion}

NEC is the most common and lethal gastrointestinal pathology that affects premature infants. Characterized by high morbidity and mortality, complex pathogenesis and devastating short-term and long-term sequelae. Only within the past decade have substantial strides been made in the understanding of the molecular mechanisms that determine NEC pathogenesis. These advances undoubtedly hold the promise to improve the development of effective preventive and diagnostic strategies to curtail the devastating consequences of the disease.

\section{Conflict of Interests}

The authors have indicated they have no financial relationships and conflict of 
interest relevant to this article to disclose.

\section{References}

[1] Stoll, B.J., Hansen, N.I., Bell, E.F., et al. (2015) Eunice Kennedy Shriver National Institute of Child Health and Human Development Neonatal Research Network. Trends in Care Practices, Morbidity, and Mortality of Extremely Preterm Neonates, 1993-2012. JAMA, 314, 1039-1051. https://doi.org/10.1001/jama.2015.10244

[2] Holman, R.C., Stoll, B.J., Curns, A.T., et al. (2006) Necrotising Enterocolitis Hospitalisations among Neonates in the United States. Paediatric and Perinatal Epidemiology, 20, 498-506. https://doi.org/10.1111/j.1365-3016.2006.00756.x

[3] Guillet, R., Stoll, B.J., Cotten, C.M., Gantz, M., McDonald, S., Poole, W.K. and Phelps, D.L. (2006) National Institute of Child Health and Human Development Neonatal Research Network. Association of H2-Blocker Therapy and Higher İncidence of Necrotizing Enterocolitis in Very Low Birth Weight İnfants. Pediatrics, 117, 137-142. https://doi.org/10.1542/peds.2005-1543

[4] Horbar, J.D., Badger, G.J., Carpenter, J.H., Fanaroff, A.A., Kilpatrick, S., LaCorte, M., Phibbs, R. and Soll, R.F. (2002) Members of the Vermont Oxford Network. Trends in Mortality and Morbidity for Very Low Birth Weight İnfants, 1991-1999. Pediatrics, 110, 143-151. https://doi.org/10.1542/peds.110.1.143

[5] Yee, W.H., Soraisham, A.S., Shah, V.S., et al. (2012) Incidence and Timing of Presentation of Necrotizing Enterocolitis in Preterm İnfants. Pediatrics, 129, 298304. https://doi.org/10.1542/peds.2011-2022

[6] Luig, M., Lui, K., NSW \& ACT NICUS Group (2005) Epidemiology of Necrotizing Enterocolitis-Part II: Risks and Susceptibility of Premature Infants during the Surfactant Era: A Regional Study. Journal of Paediatrics and Child Health, 41, 174179. https://doi.org/10.1111/j.1440-1754.2005.00583.x

[7] Luig, M., Lui, K., NSW \& ACT NICUS Group (2005) Epidemiology of Necrotizing Enterocolitis-Part I: Changing Regional Trends in Extremely Preterm İnfants over 14 Years. Journal of Paediatrics and Child Health, 41, 169-173. https://doi.org/10.1111/j.1440-1754.2005.00582.x

[8] Sankaran, K., Puckett, B., Lee, D.S., et al. (2004) Variations in İncidence of Necrotizing Enterocolitis in Canadian Neonatal İntensive Care Units. Journal of Pediatric Gastroenterology and Nutrition, 39, 366-372. https://doi.org/10.1097/00005176-200410000-00012

[9] Stoll, B.J., Hansen, N.I., Bell, E.F., et al. (2010) Eunice Kennedy Shriver National Institute of Child Health and Human Development Neonatal Research Network. Neonatal Outcomes of Extremely Preterm Infants from the NICHD Neonatal Research Network. Pediatrics, 126, 443-456. https://doi.org/10.1542/peds.2009-2959

[10] Christensen, R.D., Lambert, D.K., Baer, V.L. and Gordon, P.V. (2013) Necrotizing Enterocolitis in Term İnfants. Clinics in Perinatology, 40, 69-78.

https://doi.org/10.1016/j.clp.2012.12.007

[11] Neu, J. and Walker, W.A. (2011) Necrotizing Enterocolitis. The New England Journal of Medicine, 364, 255-264. https://doi.org/10.1056/NEJMra1005408

[12] Tanner, S.M., et al. (2015) Pathogenesis of Necrotizing Enterocolitis: Modeling the İnnate İmmune Response. American Journal of Pathology, 185, 4-16.

[13] Sodhi, C.P., et al. (2010) Toll-Like Receptor-4 İnhibits Enterocyte Proliferation via İmpaired $\beta$-Catenin Signaling in Necrotizing Enterocolitis. Gastroenterology, 138, 185-196. https://doi.org/10.1053/j.gastro.2009.09.045

[14] Gribar, S.C., et al. (2009) Reciprocal Expression and Signaling of TLR4 and TLR9 in 
the Pathogenesis and Treatment of Necrotizing Enterocolitis. The Journal of Immunology, 182, 636-646. https://doi.org/10.4049/jimmunol.182.1.636

[15] Lu, P., Sodhi, C.P. and Hackam, D.J. (2014) Toll-Like Receptor Regulation of Intestinal Development and Inflammation in the Pathogenesis of Necrotizing Enterocolitis. Pathophysiology, 21, 81-93. https://doi.org/10.1016/j.pathophys.2013.11.007

[16] Yazji, I., et al. (2013) Endothelial TLR4 Activation İmpairs İntestinal Microcirculatory Perfusion in Necrotizing Enterocolitis via eNOS-NO-Nitrite Signaling. Proceedings of the National Academy of Sciences, 110, 9451-9456. https://doi.org/10.1073/pnas.1219997110

[17] Afrazi, A., et al. (2014) Toll-Like Receptor 4-Mediated Endoplasmic Reticulum Stress in İntestinal Crypts İnduces Necrotizing Enterocolitis. The Journal of Biological Chemistry, 289, 9584-9599. https://doi.org/10.1074/jbc.M113.526517

[18] Deplancke, B. and Gaskins, H.R. (2001) Microbial Modulation of İnnate Defense: Goblet Cells and the Intestinal Mucus Layer. The American Journal of Clinical Nutrition, 73, 1131-1141.

[19] Berseth, C.L. (1996) Gastrointestinal Motility in the Neonate. Clinics in Perinatology, 23, 179-190.

[20] Berseth, C.L. (1989) Gestational Evolution of Small İntestine Motility in Preterm and Term İnfants. The Journal of Pediatrics, 115, 646-651. https://doi.org/10.1016/S0022-3476(89)80302-6

[21] Hyman, P. and Thapar, N. (2013) Pediatric Neurogastroenterology: Gastrointestinal Motility and Functional Disorders in Children, Clinical Gastroenterology. In: Di Faure, L.T., Ed., Springer Inc., 257-270.

[22] Hackam, D.J., Upperman, J.S., Grishin, A. and Ford, H.R. (2005) Disordered Enterocyte Signaling and İntestinal Barrier Dysfunction in the Pathogenesis of Necrotizing Enterocolitis. Semin. Journal of Pediatric Surgery, 14, 49-57. https://doi.org/10.1053/j.sempedsurg.2004.10.025

[23] Reisinger, K.W., et al. (2014) Breast-Feeding İmproves Gut Maturation Compared with Formula Feeding in Preterm Babies. Journal of Pediatric Gastroenterology and Nutrition, 59, 720-724. https://doi.org/10.1097/MPG.0000000000000523

[24] Lebenthal, A. and Lebenthal, E. (1999) The Ontogeny of the Small Intestinal Epithelium. Journal of Parenteral and Enteral Nutrition, 23, 3-6. https://doi.org/10.1177/014860719902300502

[25] Watkins, D.J. and Besner, G.E. (2013) The Role of the İntestinal Microcirculation in Necrotizing Enterocolitis. Seminars in Pediatric Surgery, 22, 83-87. https://doi.org/10.1053/j.sempedsurg.2013.01.004

[26] Anand, R.J., Leaphart, C.L., Mollen, K.P. and Hackam, D.J. (2007) The Role of the Intestinal Barrier in the Pathogenesis of Necrotizing Enterocolitis. Shock, 27, 124133. https://doi.org/10.1097/01.shk.0000239774.02904.65

[27] Liu, Z., Li, N. and Neu, J. (2005) Tight Junctions, Leaky İntestines, and Pediatric Diseases. Acta Paediatrica, 94, 386-393. https://doi.org/10.1111/j.1651-2227.2005.tb01904.x

[28] Caplan, M.S., Simon, D. and Jilling, T. (2005) The Role of PAF, TLR, and the Inflammatory Response in Neonatal Necrotizing Enterocolitis. Seminars in Pediatric Surgery, 14, 145-151. https://doi.org/10.1053/j.sempedsurg.2005.05.002

[29] Dingle, B.M., et al. (2013) FoxP3 ${ }^{+}$Regulatory T Cells Attenuate Experimental Necrotizing Enterocolitis. PLoS ONE, 8, e82963.

https://doi.org/10.1371/journal.pone.0082963 
[30] Weitkamp, J.H., et al. (2014) Small İntestinal İntraepithelial TCR $\gamma \delta^{+} \mathrm{T}$ Lymphocytes Are Present in the Premature İntestine but Selectively Reduced in Surgical Necrotizing Enterocolitis. PLoS ONE, 9, e99042. https://doi.org/10.1371/journal.pone.0099042

[31] Frost, B.L. and Caplan, M.S. (2013) Necrotizing Enterocolitis: Pathophysiology, Platelet-Activating Factor, and Probiotics. Seminars in Pediatric Surgery, 22, 88-93. https://doi.org/10.1053/j.sempedsurg.2013.01.005

[32] Maheshwari, A. (2015) Immunologic and Hematological Abnormalities in Necrotizing Enterocolitis. Clinics in Perinatology, 42, 567-585. https://doi.org/10.1016/j.clp.2015.04.014

[33] Rabinowitz, S.S., et al. (2001) Platelet-Activating Factor in İnfants at Risk for Necrotizing Enterocolitis. The Journal of Pediatrics, 138, 81-86. https://doi.org/10.1067/mpd.2001.110132

[34] Chatterton, D.E., Nguyen, D.N., Bering, S.B. and Sangild, P.T. (2013) Antiİnflammatory Mechanisms of Bioactive Milk Proteins in the İntestine of Newborns. The International Journal of Biochemistry \& Cell Biology, 45, 1730-1747. https://doi.org/10.1016/j.biocel.2013.04.028

[35] Soliman, A., et al. (2010) Platelet-Activating Factor İnduces TLR4 Expression in İntestinal Epithelial Cells: İmplication for the Pathogenesis of Necrotizing Enterocolitis. PLOS ONE, 5, e15044. https://doi.org/10.1371/journal.pone.0015044

[36] Eaton, S., Rees, C.M. and Hall, N.J. (2016) Current Research in Necrotizing Enterocolitis. Early Human Development, 97, 33-39.

https://doi.org/10.1016/j.earlhumdev.2016.01.013

[37] Caplan, M.S. (2010) Neonatal Necrotizing Enterocolitis: Clinical Observations, Pathophysiology, and Prevention. In: Martin, R.J. and Fanarof, A.A., Eds., Fanaroff and Martin's Neonatal-Perinatal Medicine: Diseases of the Fetus and Infant, 9th Edition, Mosby, Missouri, 1431-1440.

[38] Verduci, E., Banderali, G., Barberi, S., Radaelli, G., Lops, A., Betti, F., et al. (2014) Epigenetic Effects of Human Breast Milk. Nutrients, 6, 1711-1724.

https://doi.org/10.3390/nu6041711

[39] Gao, F., Zhang, J., Jiang, P., Gong, D., Wang, J.W., Xia, Y., et al. (2014) Marked Methylation Changes in İntestinal Genes during the Perinatal Period of Pretermneonates. BMC Genomics, 15, 716. https://doi.org/10.1186/1471-2164-15-716

[40] Willems, R., Krych, L., Rybicki, V., Jiang, P., Sangild, P.T., Shen, R.L., et al. (2015) Introducing Enteral Feeding İnduces İntestinal Subclinical İnflammation and Respective Chromatin Changes in Preterm Pigs. Epigenomics, 7, 553-565.

https://doi.org/10.2217/epi.15.13

[41] Trinchese, G., Cavaliere, G., Canani, R.B., Matamoros, S., Bergamo, P., De Filippo, C., et al. (2015) Human, Donkey and Cowmilk Differently Affects Energy Efficiency and İnflammatory State by Modulating Mitochondrial Function and Gut Microbiota. The Journal of Nutritional Biochemistry, 26, 1136-1146.

https://doi.org/10.1016/j.jnutbio.2015.05.003

[42] Schroeder, V.A., Mattioli, L.F., Kilkenny, T.A. and Belmont, J.M. (2014) Effects of Lactose-Containing vs Lactose-Free İnfant Formula on Postprandial Superiormesenteric Artery Flow in Term İnfants. Journal of Parenteral and Enteral Nutrition, 38, 236-242. https://doi.org/10.1177/0148607113478442

[43] Van Acker, J., de Smet, F., Muyldermans, G., Bougatef, A., Naessens, A. and Lauwers, S. (2001) Outbreak of Necrotizing Enterocolitis Associated with Enterobacter sakazakii in Powdered Milk Formula. Journal of Clinical Microbiology, 39, 293-297. https://doi.org/10.1128/JCM.39.1.293-297.2001 
[44] Rotbart, H.A. and Levin, M.J. (1983) How Contagious İs Necrotizing Enterocolitis? The Pediatric Infectious Disease, 2, 406-413. https://doi.org/10.1097/00006454-198309000-00019

[45] Scheifele, D.W. (1990) Role of Bacterial Toxins in Neonatal Necrotizing Enterocolitis. The Journal of Pediatrics, 117, S44-S46. https://doi.org/10.1016/S0022-3476(05)81129-1

[46] Scheifele, D.W., Olsen, E.M. and Pendray, M.R. (1985) Endotoxinemia and Thrombocytopenia during Neonatal Necrotizing Enterocolitis. American Journal of Clinical Pathology, 83, 227-229. https://doi.org/10.1093/ajcp/83.2.227

[47] Cheu, H.W., Brown, D.R. and Rowe, M.I. (1989) Breath Hydrogen Excretion as a Screening Test for the Early Diagnosis of Necrotizing Enterocolitis. The American Journal of Diseases of Children, 143, 156-159. https://doi.org/10.1001/archpedi.1989.02150140042017

[48] Santulli, T.V., Schullinger, J.N., Heird, W.C., Gongaware, R.D., Wigger, J., Barlow, B., et al. (1975) Acute Necrotizing Enterocolitis in İnfancy: A Review of 64 Cases. Pediatrics, 55, 376-387.

[49] Stewart, C.J., Marrs, E.C., Nelson, A., Lanyon, C., Perry, J.D., Embleton, N.D., et al. (2013) Development of the Preterm Gut Microbiome in Twins at Risk of Necrotising Enterocolitis and Sepsis. PLoS One, 8, e73465.

https://doi.org/10.1371/journal.pone.0073465

[50] Brower-Sinning, R., Zhong, D., Good, M., Firek, B., Baker, R., Sodhi, C.P., et al. (2014) Mucosa Associated Bacterial Diversity in Necrotizing Enterocolitis. PLoS One, 9, e105046. https://doi.org/10.1371/journal.pone.0105046

[51] Sharma, R. and Hudak, M.L. (2013) A Clinical Perspective of Necrotizing Enterocolitis: Past, Present, and Future. Clinics in Perinatology, 40, 27-51.

https://doi.org/10.1016/j.clp.2012.12.012

[52] Salhab, W.A., Perlman, J.M., Silver, L. and Sue Broyles, R. (2004) Necrotizing Enterocolitis and Neurodevelopmental Outcome in Extremely Low Birth Weight Infants $<1000 \mathrm{~g}$. Journal of Perinatology, 24, 534-540. https://doi.org/10.1038/sj.jp.7211165

[53] Heida, F.H., Hulscher, J.B., Schurink, M., Timmer, A., Kooi, E.M., Bos, A.F., et al. (2015) Intestinal Fatty Acid-Binding Protein Levels in Necrotizing Enterocolitis Correlate with Extent of Necrotic Bowel: Results from a Multicenter Study. Journal of Pediatric Surgery, 50, 1115-1118. https://doi.org/10.1016/j.jpedsurg.2014.11.037

[54] Zani, A. and Pierro, A. (2015) Necrotizing Enterocolitis: Controversies and Challenges. F1000Research, 4, pii: F1000 Faculty Rev-1373. https://doi.org/10.12688/f1000research.6888.1

[55] Nantais-Smith, L. and Kadrofske, M. (2015) Noninvasive Biomarkers of Necrotizing Enterocolitis. The Journal of Perinatal \& Neonatal Nursing, 29, 69-80. https://doi.org/10.1097/JPN.0000000000000082

[56] Ng, P.C., Ma, T.P. and Lam, H.S. (2015) The Use of Laboratory Biomarkers for Surveillance, Diagnosis and Prediction of Clinical Outcomes in Neonatal Sepsis and Necrotising Enterocolitis. Archives of Disease in Childhood Fetal and Neonatal Edition, 100, F448-F452. https://doi.org/10.1136/archdischild-2014-307656

[57] Niemarkt, H.J., et al. (2015) Necrotizing Enterocolitis: A Clinical Review on Diagnostic Biomarkers and the Role of the İntestinal Microbiota. Inflammatory Bowel Diseases, 21, 436-444. https://doi.org/10.1097/MIB.0000000000000184

[58] Ng, P.C. (2014) Biomarkers of Necrotising Enterocolitis. Seminars in Fetal and Neonatal Medicine, 19, 33-38. https://doi.org/10.1016/j.siny.2013.09.002 
[59] Thuijls, G., et al. (2010) Non-İnvasive Markers for Early Diagnosis and Determination of the Severity of Necrotizing Enterocolitis. Annals of Surgery, 251, 11741180. https://doi.org/10.1097/SLA.0b013e3181d778c4

[60] Schurink, M., et al. (2015) Intestinal Fatty Acid-Binding Protein as a Diagnostic Marker for Complicated and Uncomplicated Necrotizing Enterocolitis: A Prospective Cohort Study. PLoS ONE, 10, e0121336.

https://doi.org/10.1371/journal.pone.0121336

[61] Evennett, N., Hall, N., Pierro, A. and Eaton, S. (2010) Urinary İntestinal Fatty Acid-Binding Protein Concentration Predicts Extent of Disease in Necrotizing Enterocolitis. Journal of Pediatric Surgery, 45, 735-740.

https://doi.org/10.1016/j.jpedsurg.2009.09.024

[62] Sylvester, K.G., Ling, X.B., Liu, G.Y., Kastenberg, Z.J., Ji, J., Hu, Z., et al. (2014) Urine Protein Biomarkers for the Diagnosis and Prognosis of Necrotizing Enterocolitis in İnfants. Journal of Pediatrics, 164, 607-612 e7. https://doi.org/10.1016/j.jpeds.2013.10.091

[63] Sylvester, K.G., Ling, X.B., Liu, G.Y., Kastenberg, Z.J., Ji, J., Hu, Z., et al. (2014) A Novel Urine Peptide Biomarker-Based Algorithm for the Prognosis of Necrotising Enterocolitis in Human İnfants. Gut, 63, 1284-1292.

https://doi.org/10.1136/gutjnl-2013-305130

[64] Bohnhorst, B. (2013) Usefulness of Abdominal Ultrasound in Diagnosing Necrotising Enterocolitis. Archives of Disease in Childhood - Fetal and Neonatal Edition, 98, 445-450. https://doi.org/10.1136/archdischild-2012-302848

[65] Epelman, M., Daneman, A., Navarro, O.M., Morag, I., Moore, A.M., Kim, J.H., et al. (2007) Necrotizing Enterocolitis: Review of State-of-the-Art İmaging Findings with Pathologic Correlation. Radiographics, 27, 285-305. https://doi.org/10.1148/rg.272055098

[66] Dordelmann, M., Rau, G.A., Bartels, D., Linke, M., Derichs, N., Behrens, C., et al. (2009) Evaluation of Portal Venous Gas Detected by Ultrasound Examination for Diagnosis of Necrotising Enterocolitis. Archives of Disease in Childhood-Fetal and Neonatal Edition, 94, 183-187. https://doi.org/10.1136/adc.2007.132019

[67] Faingold, R., Daneman, A., Tomlinson, G., Babyn, P.S., Manson, D.E., Mohanta, A., et al. (2005) Necrotizing Enterocolitis: Assessment of Bowel Viability with Color Doppler US. Radiology, 235, 587-594. https://doi.org/10.1148/radiol.2352031718

[68] Silva, C.T., Daneman, A., Navarro, O.M., et al. (2007) Correlation of Sonographic Findings and Outcome in Necrotizing Enterocolitis. Pediatric Radiology, 37, 274282. https://doi.org/10.1007/s00247-006-0393-x

[69] Murdoch, E.M., Sinha, A.K., Shanmugalingam, S.T., et al. (2006) Doppler Flow Velocimetry in the Superior Mesenteric Artery on the First Day of Life in Preterm Infants and the Risk of Neonatal Necrotizing Enterocolitis. Pediatrics, 118, 19992003. https://doi.org/10.1542/peds.2006-0272

[70] Yikilmaz, A., Hall, N.J., Daneman, A., et al. (2014) Prospective Evaluation of the İmpact of Sonography on the Management and Surgical İntervention of Neonates with Necrotizing Enterocolitis. Pediatric Surgery International, 30, 1231-1240. https://doi.org/10.1007/s00383-014-3613-8

[71] DeWitt, A.G., Charpie, J.R., Donohue, J.E., Yu, S. and Owens, G.E. (2014) Splanchnic Near-İnfrared Spectroscopy and Risk of Necrotizing Enterocolitis after Neonatal Heart Surgery. Pediatric Cardiology, 35, 1286-1294.

https://doi.org/10.1007/s00246-014-0931-5

[72] Patel, A.K., Lazar, D.A., Burrin, D.G., Smith, E.O., Magliaro, T.J., Stark, A.R., et al. (2014) Abdominal Near-İnfrared Spectroscopy Measurements Are Lower in Pre- 
term İnfants at Risk for Necrotizing Enterocolitis. Pediatric Critical Care Medicine, 15, 735-741. https://doi.org/10.1097/PCC.0000000000000211

[73] Cortez, J., Gupta, M., Amaram, A., Pizzino, J., Sawhney, M. and Sood, B.G. (2011) Noninvasive Evaluation of Splanchnic Tissue Oxygenation Using Near-İnfrared Spectroscopy in Preterm Neonates. The Journal of Maternal-Fetal \& Neonatal Medicine, 24, 574-582. https://doi.org/10.3109/14767058.2010.511335

[74] Section on, Breastfeeding (2012) Breastfeeding and the Use of Human Milk. Pediatrics, 129, 827-841. https://doi.org/10.1542/peds.2011-3552

[75] Pammi, M. and Abrams, S.A. (2015) Oral Lactoferrin for the Prevention of Sepsis and Necrotizing Enterocolitis in Preterm Infants. The Cochrane Database of Systematic Reviews, 2, CD007137. https://doi.org/10.1002/14651858.cd007137.pub4

[76] Lonnerdal, B. (2010) Bioactive Proteins in Human Milk: Mechanisms of Action. Journal of Pediatrics, 156, 26-30. https://doi.org/10.1016/j.jpeds.2009.11.017

[77] Good, M., et al. (2015) Breast Milk Protects against the Development of Necrotizing Enterocolitis through İnhibition of Toll-Like Receptor 4 in the İntestinal Epithelium via Activation of the Epidermal Growth Factor Receptor. Mucosal Immunology, 8, 1166-1179. https://doi.org/10.1038/mi.2015.30

[78] Neal, M.D., et al. (2012) Toll-Like Receptor 4 İs Expressed on İntestinal Stem Cells and Regulates Their Proliferation and Apoptosis via the p53 Up-Regulated Modulator of Apoptosis. The Journal of Biological Chemistry, 287, 37296-37308. https://doi.org/10.1074/jbc.M112.375881

[79] Good, M., Sodhi, C.P. and Hackam, D.J. (2014) Evidence-Based Feeding Strategies before and after the Development of Necrotizing Enterocolitis. Expert Review of Clinical Immunology, 10, 875-884. https://doi.org/10.1586/1744666X.2014.913481

[80] Quigley, M. and McGuire, W. (2014) Formula versus Donor Breast Milk for Feeding Preterm or Low Birth Weight İnfants. The Cochrane Database of Systematic Reviews, 4, CD002971. https://doi.org/10.1002/14651858.cd002971.pub3

[81] Sullivan, S., et al. (2010) An Exclusively Human Milk-Based Diet İs Associated with a Lower Rate of Necrotizing Enterocolitis than a Diet of Human Milk and Bovine Milk-Based Products. Journal of Pediatrics, 156, 562-567 e1. https://doi.org/10.1016/j.jpeds.2009.10.040

[82] Neu, J. (2014) Probiotics and Necrotizing Enterocolitis. Clinics in Perinatology, 41, 967-978. https://doi.org/10.1016/j.clp.2014.08.014

[83] Robinson, J. (2014) Cochrane in Context: Probiotics for Prevention of Necrotizing Enterocolitis in Preterm İnfants. Evidence-Based Child Health, 9, 672-674. https://doi.org/10.1002/ebch.1977

[84] Vongbhavit, K. and Underwood, M.A. (2016) Prevention of Necrotizing Enterocolitis through Manipulation of the İntestinal Microbiota of the Premature İnfant. Clinical Therapeutics, 38, 716-732. https://doi.org/10.1016/j.clinthera.2016.01.006

[85] Coggins, S.A., Wynn, J.L. and Weitkamp, J.H. (2015) Infectious Causes of Necrotizing Enterocolitis. Clinics in Perinatology, 42, 133-154. https://doi.org/10.1016/j.clp.2014.10.012

[86] Neu, J. (2015) Preterm İnfant Nutrition, Gut Bacteria, and Necrotizing Enterocolitis. Current Opinion in Clinical Nutrition \& Metabolic Care, 18, 285-288. https://doi.org/10.1097/MCO.0000000000000169

[87] Fleming, P., Hall, N.J. and Eaton, S. (2015) Probiotics and Necrotizing Enterocolitis. Pediatric Surgery International, 31, 1111-1118. https://doi.org/10.1007/s00383-015-3790-0

[88] AlFaleh, K. and Anabrees, J. (2014) Probiotics for Prevention of Necrotizing En- 
terocolitis in Preterm İnfants. Evidence-Based Child Health, 9, 584-671. https://doi.org/10.1002/ebch.1976

[89] Downard, C.D., et al. (2012) Treatment of Necrotizing Enterocolitis: An American Pediatric Surgical Association Outcomes and Clinical Trials Committee Systematic Review. Journal of Pediatric Surgery, 47, 2111-2122. https://doi.org/10.1016/j.jpedsurg.2012.08.011

[90] Floch, M.H., et al. (2015) Recommendations for Probiotic Use-2015 Update: Proceedings and Consensus Opinion. Journal of Clinical Gastroenterology, 49, 69-73. https://doi.org/10.1097/mcg.0000000000000420

[91] Houghteling, P.D. and Walker, W.A. (2015) From Birth to "İmmunohealth", Allergies and Enterocolitis. Journal of Clinical Gastroenterology, 49, 7-12. https://doi.org/10.1097/MCG.0000000000000355

[92] Shaffiey, S.A., et al. (2016) Intestinal Stem Cell Growth and Differentiation on a Tubular Scaffold with Evaluation in Small and Large Animals. Regenerative Medicine, 11, 45-61. https://doi.org/10.2217/rme.15.70

[93] Good, M., et al. (2014) Lactobacillus rhamnosus HN001 Decreases the Severity of Necrotizing Enterocolitis in Neonatal Mice and Preterm Piglets: Evidence in Mice for a Role of TLR9. American Journal of Physiology-Gastrointestinal and Liver Physiology, 306, 1021-1032. https://doi.org/10.1152/ajpgi.00452.2013

[94] Zani, A., Eaton, S., Puri, P., et al. (2015) International Survey on the Management of Necrotizing Enterocolitis. European Journal of Pediatric Surgery, 25, 27-33. https://doi.org/10.1055/s-0034-1387942

[95] Shah, D. and Sinn, J.K. (2012) Antibiotic Regimens for the Empirical Treatment of Newborn İnfants with Necrotising Enterocolitis. The Cochrane Database of Systematic Reviews, 8, CD007448. https://doi.org/10.1002/14651858.cd007448.pub2

[96] Stey, A., et al. (2015) Outcomes and Costs of Surgical Treatments of Necrotizing Enterocolitis. Pediatrics, 135, 1190-1197. https://doi.org/10.1542/peds.2014-1058

[97] Hall, N.J., Eaton, S. and Pierro, A. (2013) Royal Australasia of Surgeons Guest Lecture. Necrotizing Enterocolitis: Prevention, Treatment, and Outcome. Journal of Pediatric Surgery, 48, 2359-2367. https://doi.org/10.1016/j.jpedsurg.2013.08.006

[98] Rao, S.C., Basani, L., Simmer, K., Samnakay, N. and Deshpande, G. (2011) Peritoneal Drainage versus Laparotomy as İnitial Surgical Treatment for Perforated Necrotizing Enterocolitis or Spontaneous İntestinal Perforation in Preterm Low Birth Weight İnfants. The Cochrane Database of Systematic Reviews, CD006182. https://doi.org/10.1002/14651858.cd006182.pub2

[99] Raval, M.V., Hall, N.J., Pierro, A. and Moss, R.L. (2013) Evidence-Based Prevention and Surgical Treatment of Necrotizing Enterocolitis-A Review of Randomized Controlled Trials. Seminars in Pediatric Surgery, 22, 117-121.

https://doi.org/10.1053/j.sempedsurg.2013.01.009

[100] Rees, C.M., et al. (2008) Peritoneal Drainage or Laparotomy for Neonatal Bowel Perforation? A Randomized Controlled Trial. Annals of Surgery, 248, 44-51. https://doi.org/10.1097/SLA.0b013e318176bf81

[101] Pammi, M. and Haque, K.N. (2015) Pentoxifylline for Treatment of Sepsis and Necrotizing Enterocolitis in Neonates. The Cochrane Database of Systematic Reviews, 3, Cd004205. https://doi.org/10.1002/14651858.cd004205.pub3

[102] Akdag, A., Dilmen, U., Haque, K., Dilli, D., Erdeve, O. and Goekmen, T. (2014) Role of Pentoxifylline and/or IgM-Enriched Intravenous İmmunoglobulin in the Management of Neonatal Sepsis. American Journal of Perinatology, 31, 905-912. https://doi.org/10.1055/s-0033-1363771 
[103] Travadi, J., Patole, S., Charles, A., Dvorak, B., Doherty, D. and Simmer, K. (2006) Pentoxifylline Reduces the İncidence and Severity of Necrotizing Enterocolitis in a Neonatal rat Model. Pediatric Research, 60, 185-189. https://doi.org/10.1203/01.pdr.0000228325.24945.ac

[104] Eaton, S., Zani, A., Pierro, A. and De, C.P. (2013) Stemcells as a Potential Therapy for Necrotizing Enterocolitis. Expert Opinion on Biological Therapy, 13, 1683-1689. https://doi.org/10.1517/14712598.2013.849690

[105] Zani, A., Cananzi, M., Fascetti-Leon, F., Lauriti, G., Smith, V.V., Bollini, S., et al. (2014) Amniotic Fluid Stem Cells İmprove Survival and Enhance Repair of Damaged İntestine in Necrotising Enterocolitis via a COX-2 Dependent Mechanism. Gut, 63, 300-309. https://doi.org/10.1136/gutjnl-2012-303735

[106] Tayman, C., Uckan, D., Kilic, E., Ulus, A.T., Tonbul, A., Murat, H.I., et al. (2011) Mesenchymal Stem Cell Therapy in Necrotizing Enterocolitis: A Rat Study. Pediatric Research, 70, 489-494. https://doi.org/10.1203/PDR.0b013e31822d7ef2

[107] Yang, J.X., Watkins, D., Chen, C.L., Bhushan, B., Zhou, Y. and Besner, G.E. (2012) Heparin-Binding Epidermal Growth Factor-Like Growth Factor Andmesenchymal Stem Cells Act Synergistically to Prevent Experimental Necrotizing Enterocolitis. Journal of the American College of Surgeons, 215, 534-545. https://doi.org/10.1016/j.jamcollsurg.2012.05.037

[108] Wei, J., Zhou, Y. and Besner, G.E. (2015) Heparin-Binding EGF-Like Growth Factor and Enteric Neural Stem Cell Transplantation in the Prevention of Experimental Necrotizing Enterocolitis in Mice. Pediatric Research, 78, 29-37. https://doi.org/10.1038/pr.2015.63

[109] Ostergaard, M.V., Bering, S.B., Jensen, M.L., Thymann, T., Purup, S., Diness, M., et al. (2014) Modulation of Intestinal Inflammation by Minimal Enteral Nutrition with Amniotic Fluid in Preterm Pigs. Journal of Parenteral and Enteral Nutrition, 38, 576-586. https://doi.org/10.1177/0148607113489313

[110] Siggers, J., Ostergaard, M.V., Siggers, R.H., Skovgaard, K., Molbak, L., Thymann, T., et al. (2013) Postnatal Amniotic Fluid İntake Reduces Gut İnflammatory Responses and Necrotizing Enterocolitis in Pretermneonates. American Journal of Physiology_ Gastrointestinal and Liver Physiology, 304, 864-875. https://doi.org/10.1152/ajpgi.00278.2012

[111] Good, M., Siggers, R.H., Sodhi, C.P., Afrazi, A., Alkhudari, F., Egan, C.E., et al. (2012) Amniotic Fluid İnhibits Toll-Like Receptor 4 Signaling in the Fetal and Neonatal İntestinal Epithelium. Proceedings of the National Academy of Sciences, 109, 11330-11335. https://doi.org/10.1073/pnas.1200856109

[112] Su, Y., Yang, J. and Besner, G.E. (2013) HB-EGF Promotes İntestinal Restitution by Affecting İntegrin-Extracellular Matrix İnteractions and İntercellular Adhesions. Growth Factors, 31, 39-55. https://doi.org/10.3109/08977194.2012.755966

[113] Chen, C.L., et al. (2012) Heparin-Binding EGF-Like Growth Factor Protects İntestinal Stem Cells from İnjury in a Rat Model of Necrotizing Enterocolitis. Laboratory Investigation, 92, 331-344. https://doi.org/10.1038/labinvest.2011.167

[114] Yang, J., Su, Y., Zhou, Y. and Besner, G.E. (2014) Heparin-Binding EGF-Like Growth Factor [HB-EGF] Therapy for Intestinal İnjury: Application and Future Prospects. Pathophysiology, 21, 95-104. https://doi.org/10.1016/j.pathophys.2013.11.008

[115] Newburg, D.S. (2009) Neonatal Protection by an İnnate İmmune System of Human Milk Consisting of Oligosaccharides and Glycans. Journal of Animal Science, 87, 26-34. https://doi.org/10.2527/jas.2008-1347

[116] Jantscher-Krenn, E., et al. (2012) The Human Milk Oligosaccharide Disialyllacto- 
N-Tetraose Prevents Necrotising Enterocolitis in Neonatal Rats. Gut, 61, 1417-1425. https://doi.org/10.1136/gutjnl-2011-301404

[117] Fitzgibbons, S.C., Ching, Y., Yu, D., et al. (2009) Mortality of Necrotizing Enterocolitis Expressed by Birth Weight Categories. Journal of Pediatric Surgery, 44, 1072 1076. https://doi.org/10.1016/j.jpedsurg.2009.02.013

[118] Rees, C.M., Pierro, A. and Eaton, S. (2007) Neurodevelopmental Outcomes of Neonates with Medically and Surgically Treated Necrotizing Enterocolitis. Archives of Disease in Childhood Fetal and Neonatal Edition, 92, 193-198. https://doi.org/10.1136/adc.2006.099929

[119] Hintz, S.R., Kendrick, D.E., Stoll, B.J., et al. (2005) Neurodevelopmental and Growth Outcomes of Extremely Low Birth Weight İnfants after Necrotizing Enterocolitis. Pediatrics, 115, 696-703. https://doi.org/10.1542/peds.2004-0569

[120] Shah, D.K., Doyle, L.W., Anderson, P.J., et al. (2008) Adverse Neurodevelopment in Preterm İnfants with Postnatal Sepsis or Necrotizing Enterocolitis İs Mediated by White Matter Abnormalities on Magnetic Resonance İmaging at Term. Journal of Pediatrics, 153, 170-175. https://doi.org/10.1016/j.jpeds.2008.02.033

Submit or recommend next manuscript to SCIRP and we will provide best service for you:

Accepting pre-submission inquiries through Email, Facebook, LinkedIn, Twitter, etc. A wide selection of journals (inclusive of 9 subjects, more than 200 journals)

Providing 24-hour high-quality service

User-friendly online submission system

Fair and swift peer-review system

Efficient typesetting and proofreading procedure

Display of the result of downloads and visits, as well as the number of cited articles

Maximum dissemination of your research work

Submit your manuscript at: http://papersubmission.scirp.org/

Or contact health@scirp.org 